\title{
Savior turns into monster: a case report
}

\begin{abstract}
Now a day's crimes against women are increasing day by day. Along with this, illicit relationships in family members are also increasing, mostly in rural population especially in joint families. Most of the times, the culprits are near relatives or from home itself. We encountered such a case in which an adolescent girl was admitted under Gynaecologist for the presenting complaints of pain abdomen with distension. On medical examination, she was found to be having almost full-term pregnancy. However, the girl of this tender age was absolutely ignorant of her pregnancy and no one in the family including her mother could suspect her teen age unmarried girl to be pregnant. The circumstances narrated by the girl shocked the family and unfolded the mystery of this unwanted pregnancy and shameful acts with her for months together by none other than her own blood relative. The pregnancy and problems of foetal anomalies occurring as a result of such incestuous sexual intimacy are beyond imagination. The outcome of pregnancy and other socio-legal issues/problems relating to such a case will be discussed in detail in this paper.
\end{abstract}

Keywords: teen-age pregnancy, anencephaly, neural tube defect (NTD), folic acid, incest
Volume 2 Issue I - 2016

\begin{abstract}
Jai Prakash Soni,Vijay Pal Khanagwal,Vincent Merry, Dinesh Chhillar,Vinod Kumar Department of Forensic Medicine, Pandit Bhagwat Dayal Sharma Post Graduate Institute of Medical Sciences, India

Correspondence: Vijay Pal Khanagwal, Professor, Department of Forensic Medicine, Pandit Bhagwat Dayal Sharma Post Graduate Institute of Medical Sciences, 27/9-J, Medical Campus, Rohtak-12400I, Haryana, India, Tel 9416478078/94I63 I2472, Email drvijaykhanagwal@gmail.com
\end{abstract}

Received: October 28, 2015 | Published: January 13, 2016

\section{Introduction}

It is a famous saying in our country that for grandparents, the grandchildren are like the interest and the children are like the principal amount and that interest is always dearer than the principal amount. But these days, social values are going down to such an extent that the pious relation in the family are also affected and the age old saying appear to have being disapproved by the society. Many a times, we come to know through newspapers or mass media about illicit relations between father and daughter, mother and son as well as between grandfather and granddaughter, grandmother and grandson. As we know that incest is not a crime in India but in many European countries it is punishable. Such illicit relationship amongst blood relations poses not only a lot of social and legal problems but medical problems too. Genetically, incest is also hazardous for whole of the family and society as various genetic defects are common in incestuous relation due to lack of recombination of DNA.

\section{Case presentation}

A 14 year old female child was brought by her mother to the Gynecology department with chief complaints of irregular menstrual cycles for 2-3 months and abdominal pain with distension for about one week. The gynaecologist examined the girl and advised ultrasonography of abdomen. Ultrasonography revealed a near full term fetus with anencephaly. When the mother was informed pregnancy of her daughter, she was shocked to know it. She asked her daughter about this. Initially, the girl could not explain anything satisfactorily but on persuasion with gentle and affectionate attitude, the girl narrated the whole story of her sexual exploitation by none other than her own grandfather who had threatened her to kill if she revealed his shameful acts to anyone. The revelation of the shameful acts of the head of the family shocked everyone and after a long discussion amongst the family, FIR was lodged against her grandfather. In the meantime, she girl had been kept under observation in the labour room. She went into labour-pains and ultimately delivered a still birth anencephalic female fetus.

\section{Autopsy findings}

The body of the still-born female foetus was received for autopsy along with requisition for preserving the material for DNA sampling for the purpose of comparing the same with that of the suspected accused. The examination revealed that it was a female anencephalic foetus with bony defect over occipital region and adjoining cervical region with upper part of thoracic region (up to the 2nd thoracic vertebrae on the back). Both ears were malformed. Neck was webbed with trunk portion was not well formed. Both eyes were prominent and eye balls were bulging out. The intra-uterine age of the foetus was between 7-8 months and it didn't show any signs of live-birth. Anencephaly along with other gross congenital malformations was not compatible with life. For the purpose of DNA proofing, one of the femur was preserved along with a bunch of scalp hair with roots.

\section{Discussion}

Incestuous relationship leads to slight malformation to gross congenital malformation. Bennett et al. in 2002 studied that the excess level of death and severe defect in the offspring of incestuous unions was $31.4 \%$. Another method of predicting this risk is to extrapolate from the data on the predicted risk to the offspring of first-cousin unions and amplify the risk based on the closer degree of relationship, thus estimating a $6.8 \%$ to $11.2 \%$ risk above the population background for significant birth defects. ${ }^{1}$ Seemanová ${ }^{2}$ studied over the Czechoslovakian children whose fathers were first degree relatives. Fewer than half of the children who were the product of incestuous unions were completely healthy. Forty-two percent of them were born with severe birth defects or suffered early death and another 11 percent were mildly mentally impaired. ${ }^{2}$ Incestuous relation increases the homozygosity. Having a high homozygosity rate is bad for a population because it will unmask recessive deleterious alleles generated by mutations, reduce heterozygote advantage, and it is detrimental to the survival of small, endangered animal populations. ${ }^{3}$ 


\section{Maternal age}

The malformation is more common in girls than boys, in whites than blacks, and in mothers at the younger and older extremes of age. ${ }^{4}$

\section{Folic acid deficiency}

It is recommended that all women of child-bearing age consume $0.4 \mathrm{mg}$ of folic acid daily, ${ }^{5}$ especially those attempting to conceive or who may possibly conceive, as this can reduce the risk to $0.03 \%{ }^{6}$

\section{Conclusion}

This case represents a link between different factors i.e incestuous relationship, maternal age, folic acid deficiency and foetal malformation. It also indicates that incestuous relationship is not fit socially as well as biologically. In this vary case, if this foetus was normal then what will be the future of that baby and how could their family accept that baby and how that teenager mother will bear the mental trauma. Above all, This case also hints towards downfall of family values and proves as an example of degradation of moral values, faith and trust in the family and society raises burning questions that when savior turns into a monster who will protect our kids and how safe are our children even at home. Incest, rape and abuse is rampant everywhere, but society is silent. It is a silent epidemic.

"I felt like an animal, and animals don't know sin, do they?"

\section{Acknowledgments}

None.

\section{Conflicts of interest}

The author declares that there are no conflicts of interest.

\section{References}

1. Bennett RL, Motulsky AG, Bittles A, et al. Genetic counseling and screening of consanguineous couples and their offspring: recommendations of the National Society of Genetic Counselors. $J$ Genet Couns. 2002;11(2):97-119.

2. Seemanová E. A Study of Children of Incestuous Matings. Hum Hered. 1971;21(2):108-128.

3. Meagher S, Penn DJ, Potts WK. Male-male competition magnifies inbreeding depression in wild house mice. Proc Natl Acad Sci. USA. 2000;97(7): 3324-3329.

4. Volpe JJ. Intracranial hemorrhage: Neural tube formation and prosencephalic development, 4th ed. Neurology of the Newborn, WB Saunders, Philadelphia, USA. 2001;3 p.

5. National Institute of Neurological Disorders and Stroke (NINDS). Anencephaly Information. 2008.

6. Ratcliffe SD. Family medicine obstetrics, 3rd ed. Mosby Elsevier publications, Philadelphia, USA. 2008. 